\title{
Multifunctional Cancer Phototherapy Using the Fluorophore-Functionalized Nanodiamond Supraparticles
}

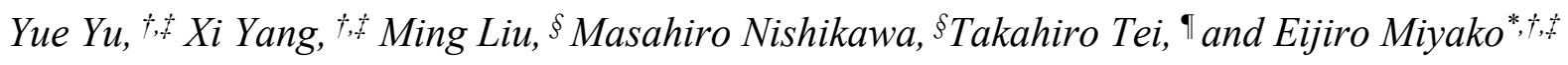

†Department of Materials and Chemistry, Nanomaterials Research Institute (NMRI), National Institute of Advanced Industrial Science and Technology (AIST), Central 5, 1-1-1 Higashi, Tsukuba, Ibaraki 305-8565, Japan.

Present address: School of Materials Science, Japan Advanced Institute of Science and Technology, 1-1 Asahidai, Nomi, Ishikawa, 923-1292, Japan

$\S$ Corporate Research Center, R\&D Headquarters, Daicel Corporation, 1239, Shinzaike, Aboshi-ku, Himeji, Hyogo 671-1283, Japan.

๑Advanced Materials Planning, R\&D Headquarters, Daicel Corporation, 2-19-1 Konan, Minato-ku, Tokyo 108-8230, Japan.

*To whom correspondence should be addressed. E-mail: e-miyako@jaist.ac.jp 
(A)

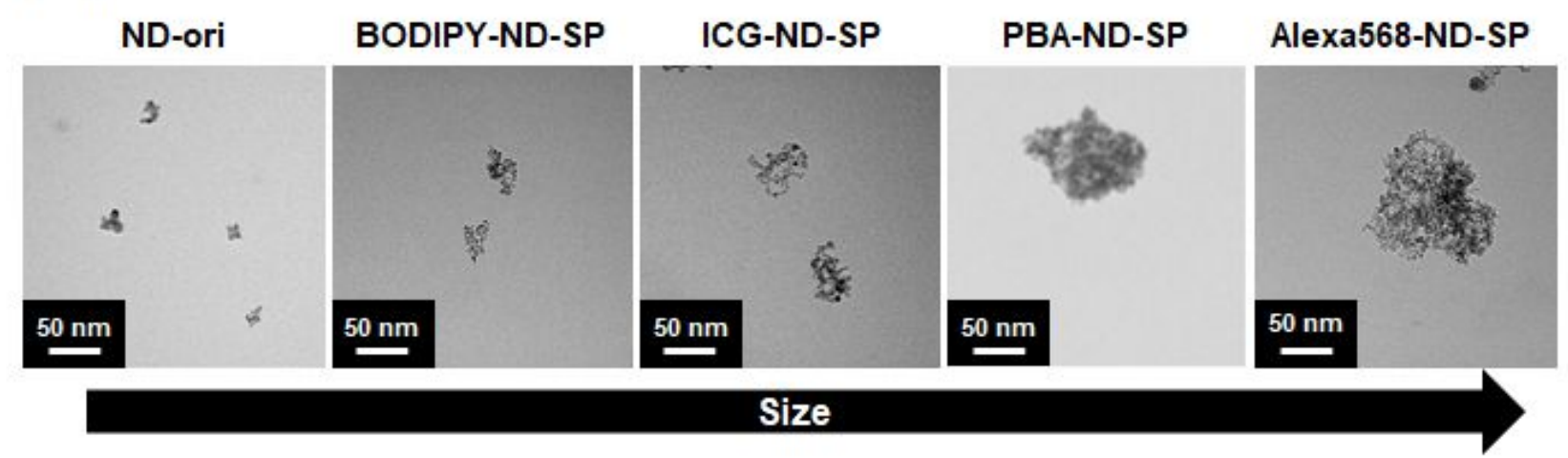

(B)

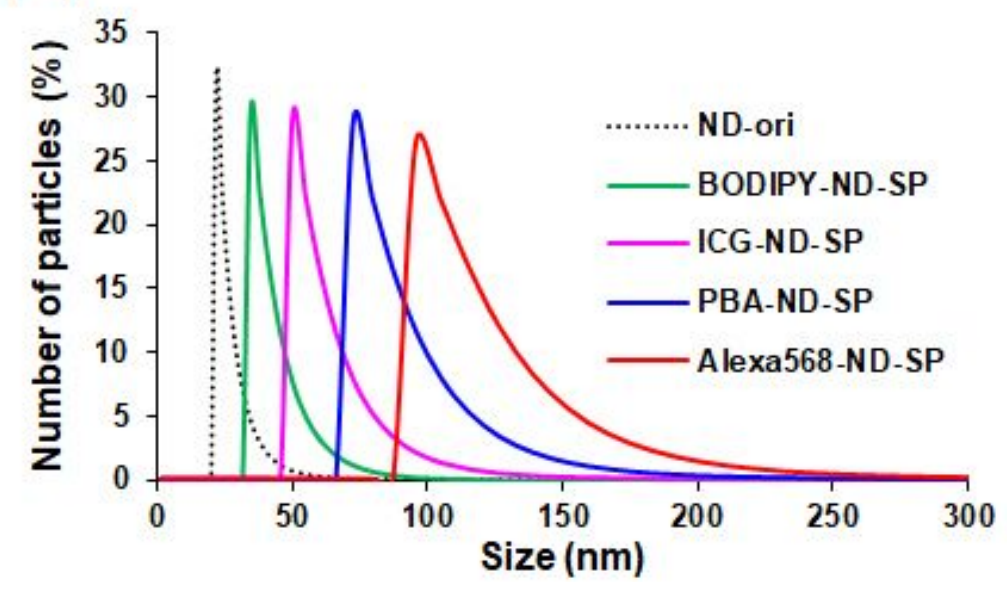

(C)

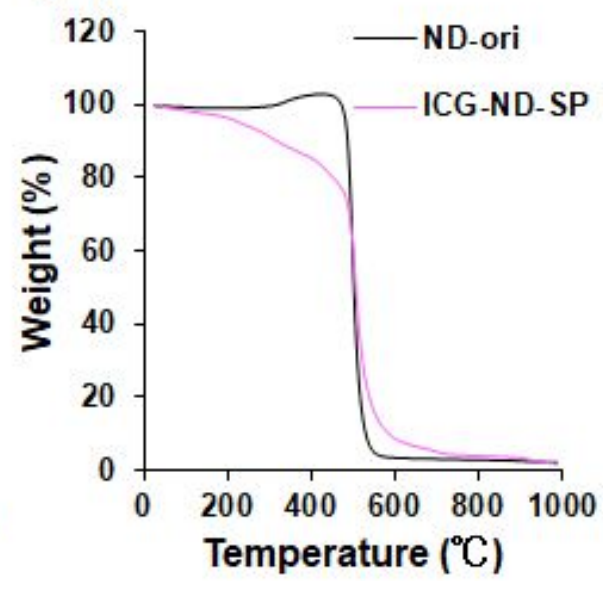

Supporting Figure S1. Synthesis and characterization of various fluorescent-dye-functionalized ND-SPs. (A) Representative TEM images of ND-ori and various fluorescent-dye-functionalized ND-SPs. (B) Size distributions of various fluorescent-dye-functionalized ND-SPs, as obtained by DLS. (C) TGA curves of ND-ori and ICG-ND-SP. 
(A)

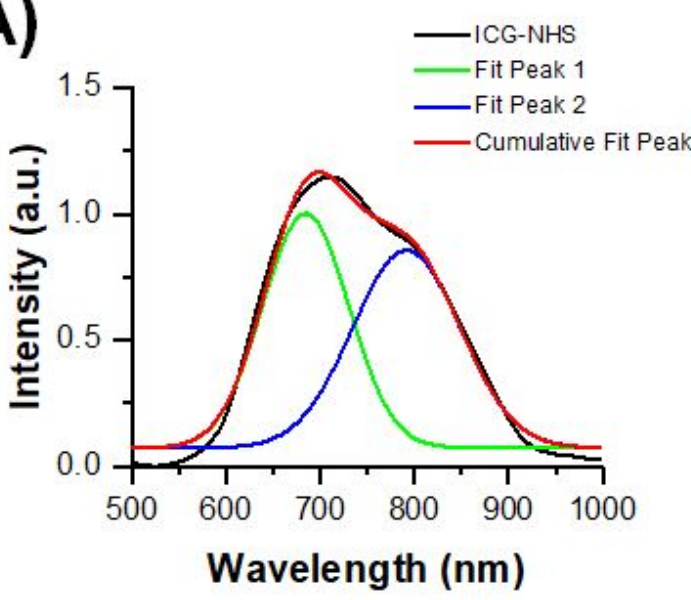

\begin{tabular}{lccc}
\hline & Center & Height & FWHM \\
\hline Fit Peak 1 & 684.67 & 0.93 & 107.64 \\
Fit Peak 2 & 791.60 & 0.78 & 134.48 \\
\hline
\end{tabular}

(B)

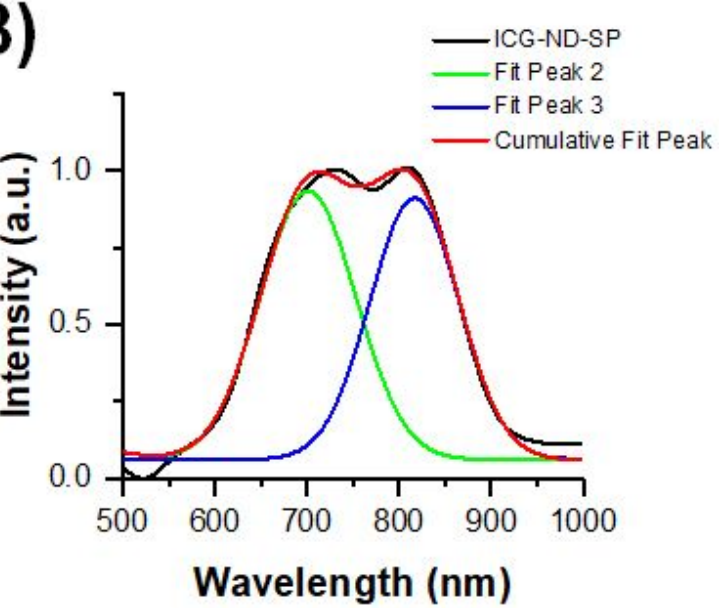

\begin{tabular}{lccc}
\hline & Center & Height & FWHM \\
\hline Fit Peak 1 & 701.13 & 0.87 & 122.55 \\
Fit Peak 2 & 816.71 & 0.85 & 113.97 \\
\hline
\end{tabular}

Supporting Figure S2. Curve fitting for UV-vis-NIR absorption spectrums of ICG (a) and ICG-ND-SP (b). Full width at half maximum (FWHM) is short for full width at half maximum. 


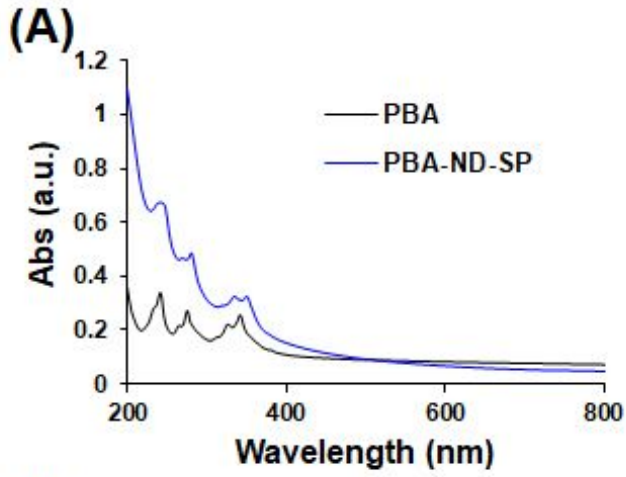

(B)

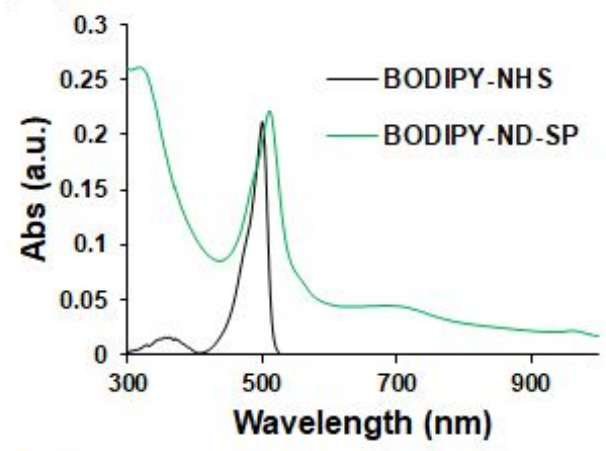

(C)

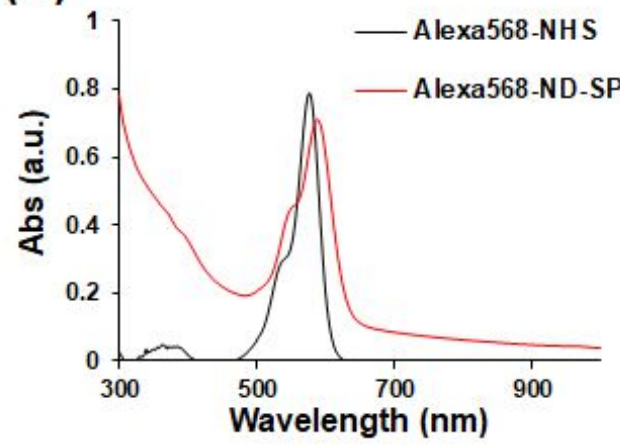

(D)

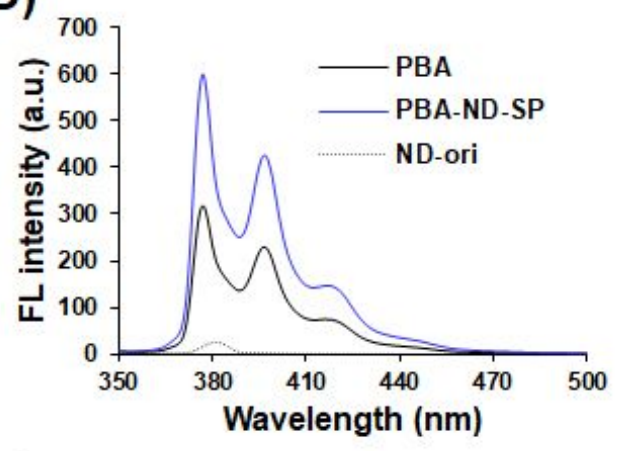

(E)

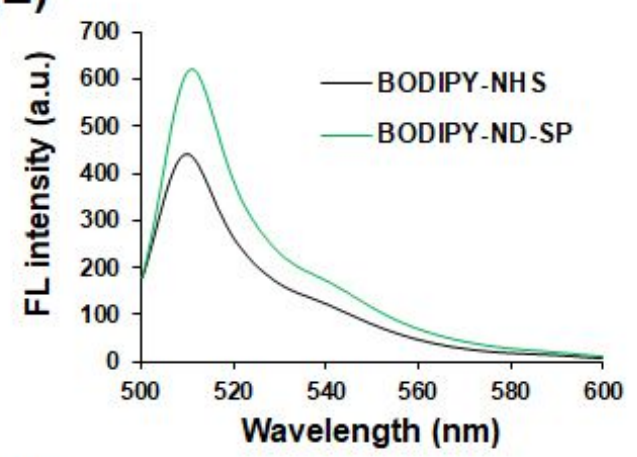

(F)

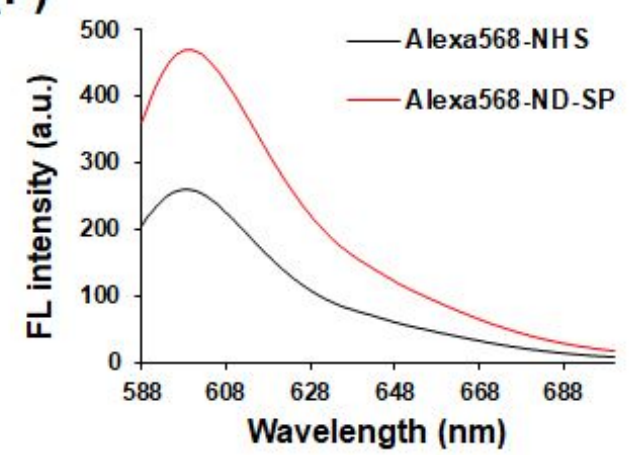

Supporting Figure S3. Optical characterization of various fluorescent-dye-functionalized ND-SPs. (A)-(C) UV-Vis-NIR absorbance spectra of various fluorescent-dye-functionalized ND-SPs. (A) The PBA concentration is $14.4 \mu \mathrm{g} \mathrm{ml}^{-1}$. The concentrations of PBA and ND in PBA-ND-SPs are 1.5 and $30 \mu \mathrm{g} \mathrm{ml}^{-1}$, respectively. (B) The BODIPY-NHS concentration is $1.34 \mu \mathrm{g} \mathrm{ml}^{-1}$. The concentrations of BODIPY and ND in BODIPY-ND-SPs are 1 and $75 \mu \mathrm{g} \mathrm{ml}^{-1}$, respectively. (C) The Alexa568-NHS concentration is $6.9 \mu \mathrm{g} \mathrm{ml}^{-1}$. The concentrations of Alexa568 and ND in Alexa568-ND-SPs are 4 and $30 \mu \mathrm{g} \mathrm{ml}^{-1}$, respectively. (D)-(F) The fluorescence (FL) intensity of various fluorescent-dye-functionalized ND-SPs. (D) The BPA concentration is $0.14 \mathrm{ng} \mathrm{ml}^{-1}$. The concentrations of PBA and ND in PBA-ND-SPs are 3 and $60 \mathrm{ng} \mathrm{ml}^{-1}$, respectively. (E) The BODIPY-NHS concentration is $5 \mathrm{ng} \mathrm{ml}^{-1}$. The concentrations of BODIPY and ND in BODIPY-ND-SPs are 40 and $3000 \mathrm{ng} \mathrm{ml}^{-1}$, respectively. (F) The Alexa568-NHS concentration is $5 \mathrm{ng} \mathrm{ml}^{-1}$. The concentrations of Alexa568 and ND in Alexa568-ND-SPs are 20 and $1500 \mathrm{ng} \mathrm{ml}^{-1}$, respectively. 
(A)

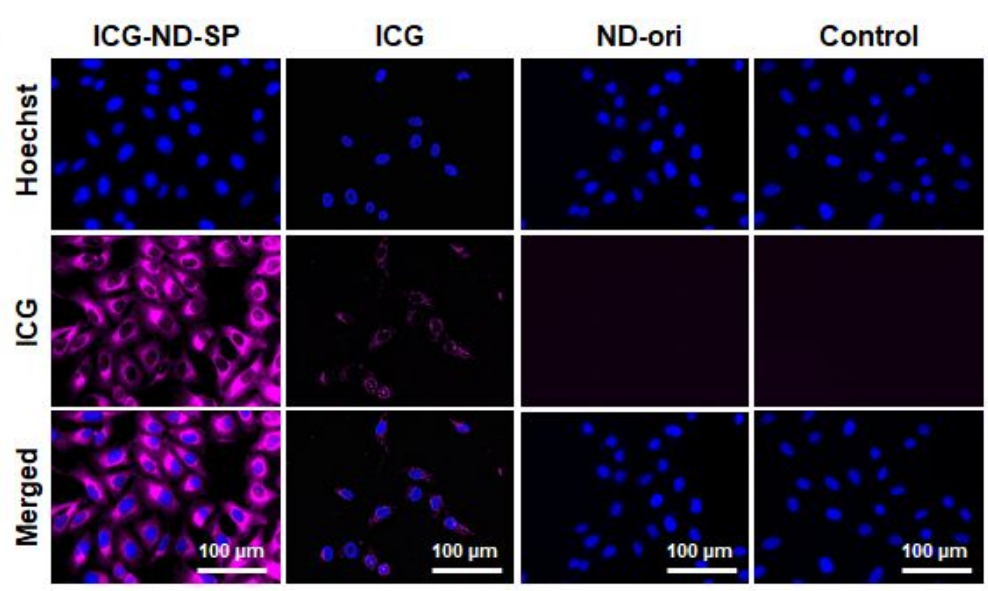

(B)

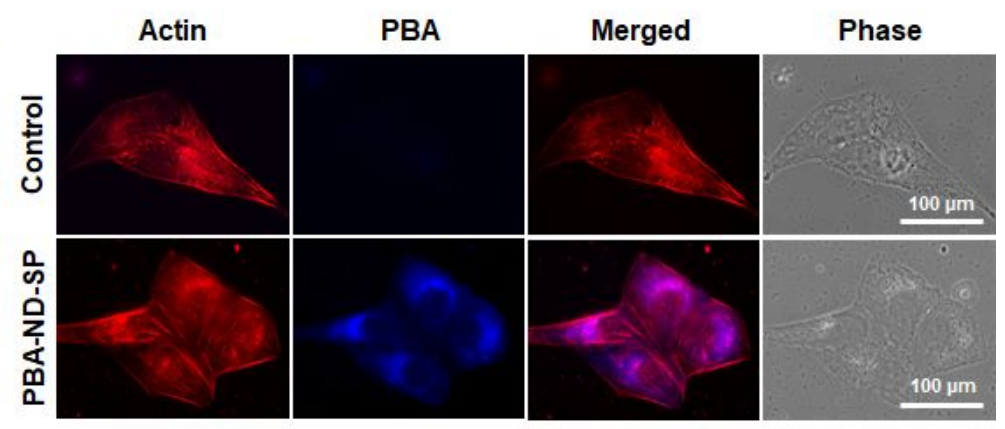

(C)

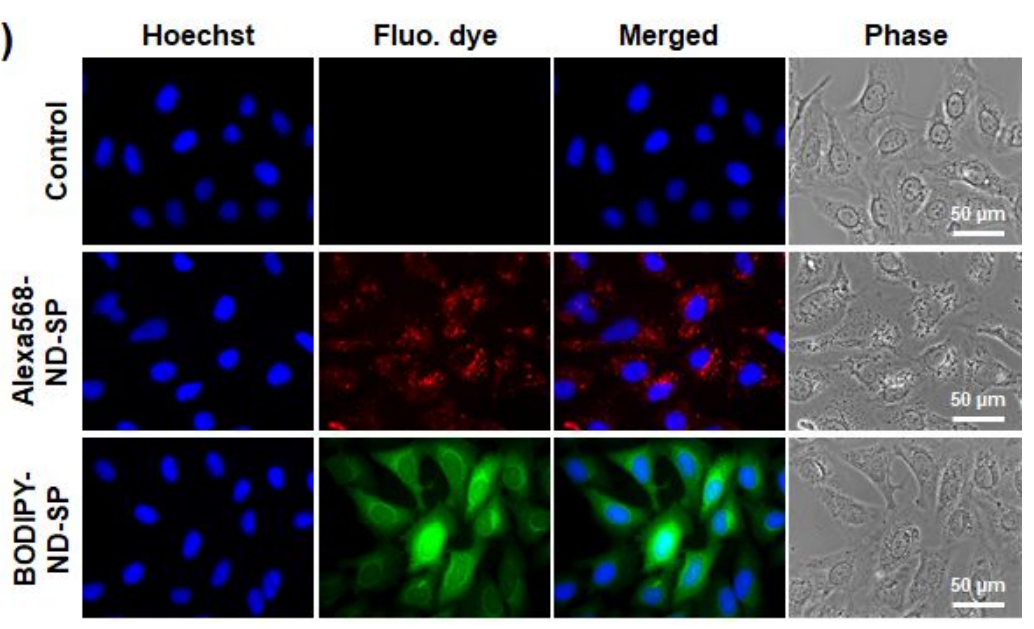

Supporting Figure S4. The fluorescence microscopy of various fluorescent-dye-functionalized ND-SPs. (A) The NIR fluorescence microscopy of the live U2OS cells treated with ICG-ND-SPs $\left(\mathrm{ICG}=1.5 \mu \mathrm{g} \mathrm{ml}^{-1}, \mathrm{ND}=6 \mu \mathrm{g} \mathrm{ml}^{-1}\right)$, ICG $\left(1.5 \mu \mathrm{g} \mathrm{ml}^{-1}\right)$, and ND-ori $\left(\mathrm{ND}=6 \mu \mathrm{g} \mathrm{ml}^{-1}\right)$ for $4 \mathrm{~h}$ at $37^{\circ} \mathrm{C}$ in $5 \% \mathrm{CO}_{2}$ atmosphere. The control without fluorescent dye was also observed under the same conditions as negative contrast. (B) The fluorescence microscopy of the U2OS cells after 24-h treatment of PBA-ND-SPs (PBA $=0.3 \mu \mathrm{g} \mathrm{ml}^{-1}, \mathrm{ND}=6 \mu \mathrm{g} \mathrm{ml}{ }^{-1}$ ). The cytoskeleton (actin) was stained by Phalloidin. (C) The fluorescence microscopy of the U2OS cells after 6-h treatment of Alexa568-ND-SPs (Alexa568 $=0.8 \mu \mathrm{g} \mathrm{ml}^{-1}, \mathrm{ND}=60 \mu \mathrm{g} \mathrm{ml}^{-1}$ ) and BODIPY-ND-SPs (BODIPY $\left.=0.8 \mu \mathrm{g} \mathrm{ml}^{-1}, \mathrm{ND}=60 \mu \mathrm{g} \mathrm{ml}^{-1}\right)$. The nucleus was stained by Hoechst 33342. The cells in panels (B) and (C) were fixed with $4 \%$ PFA before observation. 


\section{(A)}

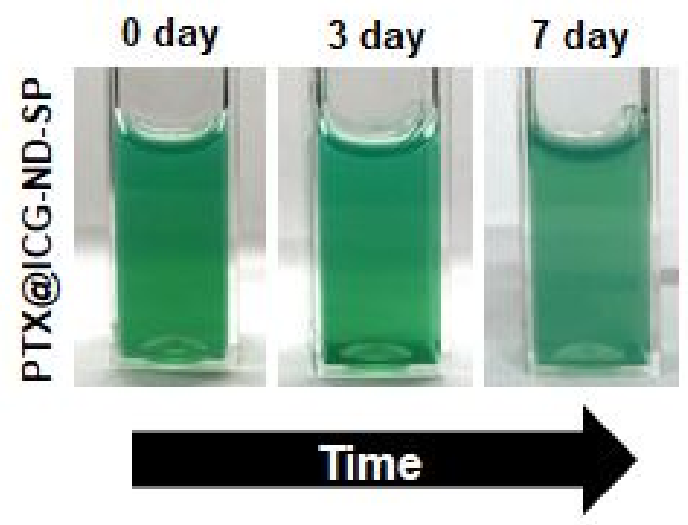

(B)

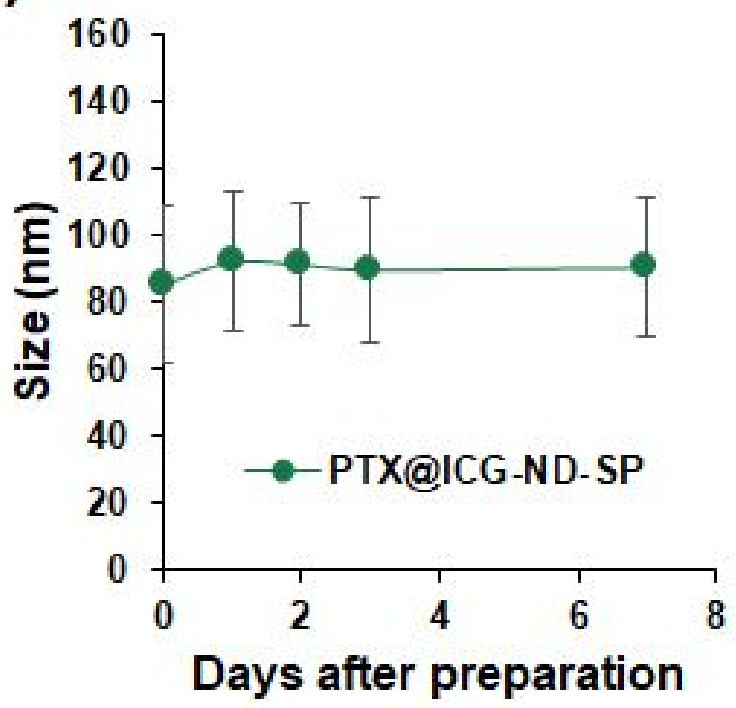

Supporting Figure S5. Dispersing stability of PTX@ICG-ND-SPs. (A) Images of PTX@ICG-ND-SPs (The concentrations of PTX, ICG, and ND-ori are 0.2, 0.06, and $0.6 \mathrm{mg} \mathrm{ml}^{-1}$, respectively) in Milli-Q water for 7 days. (B) The DLS measurements of a size of PTX@ICG-ND-SP in a solution at different time points $(0,1,2,3$, and 7 days).
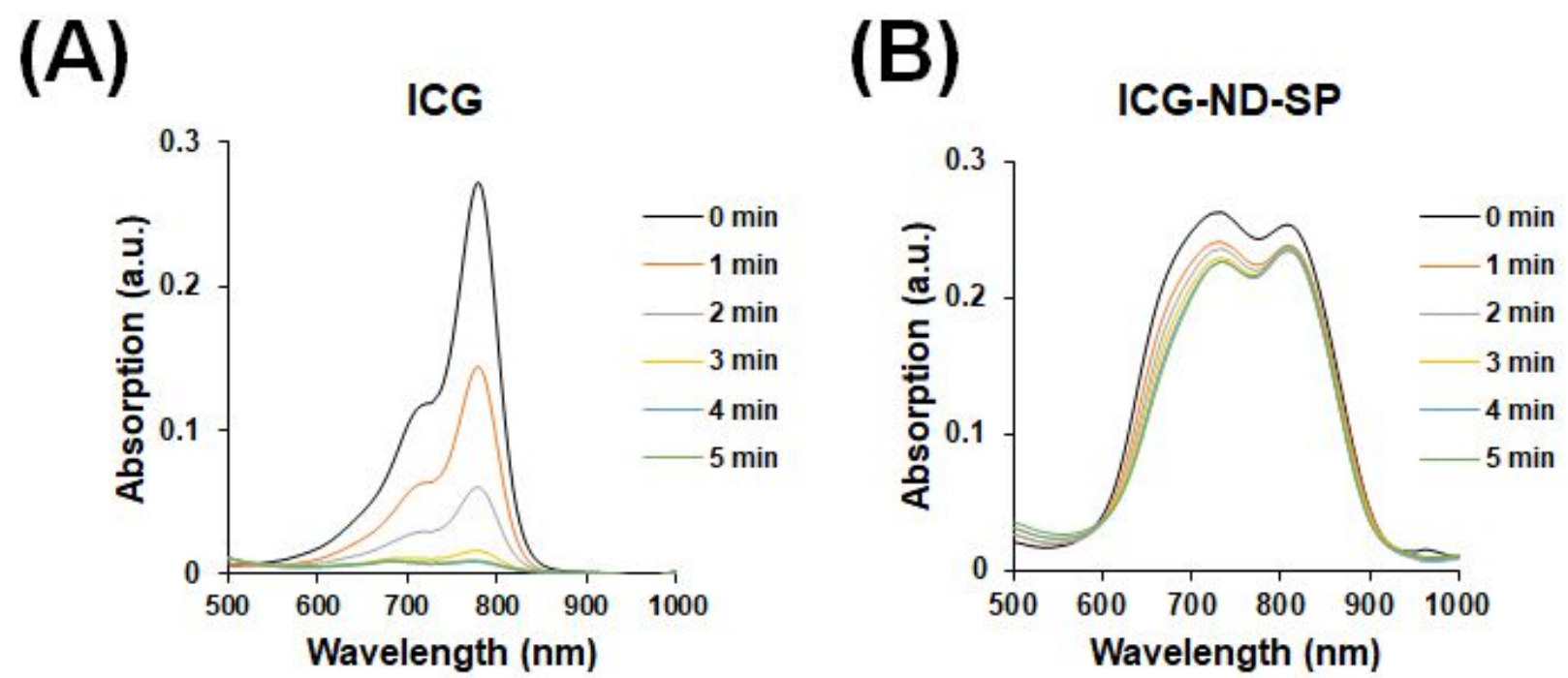

Supporting Figure S6. Photostability of ICG-ND-SPs. UV-Vis-NIR absorption spectra of ICG (A) and ICG-ND-SP (B) after different time of laser irradiation. The concentration of ICG and ND is 3.8 and $15 \mu \mathrm{g} \mathrm{ml}^{-1}$, respectively. 


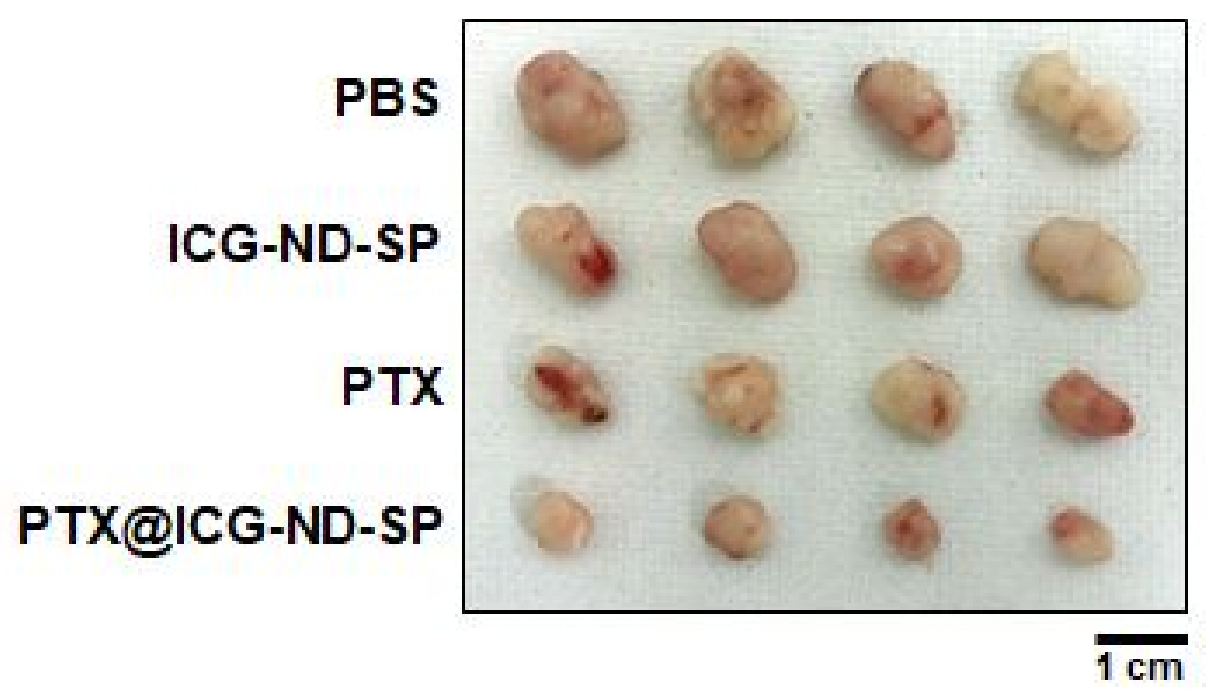

Supporting Figure S7. Photographs of the tumors isolated from mice at the end of the experiment. 
Table S1. Complete blood counts (CBCs) and biochemical parameters of the mice injected with PBS or ICG-ND-SP after one week.

\begin{tabular}{|c|c|c|c|c|c|}
\hline Method & Entry & Unit & PBS $(n=5)$ & $\begin{array}{l}\text { ICG-ND-SP } \\
(n=5)\end{array}$ & $p$ value \\
\hline & WBC & $\times 102 \mu l^{-1}$ & $39 \pm 9$ & $42 \pm 12$ & $>0.05$ \\
\hline \multirow[t]{6}{*}{ CBC } & $\mathrm{RBC}$ & $\times 104 \mu \mathrm{l}^{-1}$ & $917 \pm 52$ & $895 \pm 32$ & $>0.05$ \\
\hline & PLT & $\times 104 \mu \mathrm{l}^{-1}$ & $60 \pm 3$ & $65 \pm 2$ & $>0.05$ \\
\hline & CRP & $\mu \mathrm{g} \mathrm{ml}^{-1}$ & $1.1 \pm 0.1$ & $1.0 \pm 0.1$ & $>0.05$ \\
\hline & TP & $\mathrm{g} \mathrm{dl}^{-1}$ & $4.0 \pm 0.1$ & $4.1 \pm 0.3$ & $>0.05$ \\
\hline & ALB & $\mathrm{g} \mathrm{dl}^{-1}$ & $2.7 \pm 0.1$ & $2.7 \pm 0.3$ & $>0.05$ \\
\hline & BUN & $\mathrm{mg} \mathrm{dl}^{-1}$ & $23 \pm 2$ & $21 \pm 1$ & $>0.05$ \\
\hline \multirow[t]{5}{*}{$\begin{array}{l}\text { Biochemical } \\
\text { parameters }\end{array}$} & CRE & $\mathrm{mg} \mathrm{dl}^{-1}$ & $0.11 \pm 0.02$ & $0.09 \pm 0.02$ & $>0.05$ \\
\hline & AST & $\mathrm{IU} \mathrm{I}^{-1}$ & $60 \pm 5$ & $67 \pm 17$ & $>0.05$ \\
\hline & LDH & $\mathrm{IU} \mathrm{I}^{-1}$ & $325 \pm 39$ & $349 \pm 95$ & $>0.05$ \\
\hline & AMY & $\mathrm{IU} \mathrm{I}^{-1}$ & $1837 \pm 173$ & $1772 \pm 136$ & $>0.05$ \\
\hline & CK & $\mathrm{IU} \mathrm{I}^{-1}$ & $359 \pm 165$ & $266 \pm 187$ & $>0.05$ \\
\hline
\end{tabular}

Results are the mean \pm standard deviation of five experiments. Statistical analyses comprise the Student's t-test.

Abbreviations: ALB, albumin; AMY, amylase; AST, aspartate aminotransferase; BUN, blood urea nitrogen; $\mathrm{CK}$, creatine kinase; $\mathrm{CRE}$, creatinine; CRP, C-reactive protein; LDH, lactate dehydrogenase; PLT, platelet; RBC, red blood cell; TP, total protein; WBC, white blood cell. 
Table S2. Complete blood counts (CBCs) and biochemical parameters of the mice injected with PBS or ICG-ND-SP after four weeks.

\begin{tabular}{|c|c|c|c|c|c|}
\hline Method & Entry & Unit & PBS $(n=5)$ & $\begin{array}{l}\text { ICG-ND-SP } \\
(n=5)\end{array}$ & $p$ value \\
\hline & WBC & $\times 102 \mu l^{-1}$ & $46 \pm 8$ & $42 \pm 8$ & $>0.05$ \\
\hline \multirow[t]{6}{*}{$\mathrm{CBC}$} & $\mathrm{RBC}$ & $\times 104 \mu \mathrm{l}^{-1}$ & $897 \pm 37$ & $906 \pm 40$ & $>0.05$ \\
\hline & PLT & $\times 104 \mu \mathrm{l}^{-1}$ & $65 \pm 6$ & $61 \pm 5$ & $>0.05$ \\
\hline & CRP & $\mu \mathrm{g} \mathrm{ml}^{-1}$ & $1.0 \pm 0.2$ & $1.0 \pm 0.2$ & $>0.05$ \\
\hline & TP & $\mathrm{g} \mathrm{dl}^{-1}$ & $3.8 \pm 0.2$ & $3.8 \pm 0.2$ & $>0.05$ \\
\hline & ALB & $\mathrm{g} \mathrm{dl}^{-1}$ & $2.6 \pm 0.1$ & $2.6 \pm 0.1$ & $>0.05$ \\
\hline & BUN & $\mathrm{mg} \mathrm{dl}^{-1}$ & $17 \pm 4$ & $17 \pm 4$ & $>0.05$ \\
\hline \multirow[t]{5}{*}{$\begin{array}{l}\text { Biochemical } \\
\text { examination }\end{array}$} & CRE & $\mathrm{mg} \mathrm{dl}^{-1}$ & $0.11 \pm 0.01$ & $0.12 \pm 0.02$ & $>0.05$ \\
\hline & AST & $\mathrm{IU} \mathrm{I}^{-1}$ & $59 \pm 15$ & $59 \pm 13$ & $>0.05$ \\
\hline & LDH & $\mathrm{IU} \mathrm{I}^{-1}$ & $261 \pm 118$ & $250 \pm 77$ & $>0.05$ \\
\hline & AMY & $\mathrm{IU} \mathrm{I}^{-1}$ & $1575 \pm 74$ & $1686 \pm 135$ & $>0.05$ \\
\hline & CK & $\mathrm{IU} \mathrm{I}^{-1}$ & $228 \pm 137$ & $216 \pm 149$ & $>0.05$ \\
\hline
\end{tabular}

Results are the mean \pm standard deviation of five experiments. The statistical analyses comprise the Student's t-test.

Abbreviations: ALB, albumin; AMY, amylase; AST, aspartate aminotransferase; BUN, blood urea nitrogen; CK, creatine kinase; CRE, creatinine; CRP, C-reactive protein; LDH, lactate dehydrogenase; PLT, platelet; RBC, red blood cell; TP, total protein; WBC, white blood c 